\title{
HOW TO REDUCE CARGO DAMAGE?
}

\author{
Nurul Oktaviani ${ }^{1}$, Zahra Arin Yadia ${ }^{2}$, Nursery Nasution ${ }^{3}$, Veronica ${ }^{4}$ \\ 1. STMT Trisakti, 2. STMT Trisakti, 3. Malaysia Institute for Supply \\ Chain Innovation, 4. Malaysia Institute for Supply Chain Innovation \\ $\triangle$ Corresponding author : nuruloct@gmail.com
}

\begin{abstract}
The objective of this paper is to improve the perfomance of cargo delivery by minimazing the number of cargo damage. This paper explains the steps to reduce cargo damage and also explains what the usual reasons are that cause damage to cargo. The most important things to be noticed is how to handle the cargo and how to reduce the number of risk possibility by finding the things that may cause it.Fishbone diagrams and interview were used to collect data. Fishbone diagrams were used to identify and classify the causes and the effect of it. Therefore, this paper was explained using descriptive analysis method.The results of this paper said most of cargo damage are as follows packing torn, dent and wet. Cargo damage may occur due to 5 causes: human, methods, machines or tools, environment and material.
\end{abstract}

Keywords : performance, damage cargo, risk possibility, interview, fishbone, descriptive.

\section{Introduction}

In this past few years, the development of freight through airways is increasing.Demand for air cargo is shown by good growth in recent years. The annual forecast report by Airbus (2015) and Boeing (2015) predicts 4.4 -7.7 percent annual growth of global air cargo tonnage during the next 20 years(Azadian, Murat, \& Chinnam, 2017).The increasing of air cargo demand can also be seen from the number of freight forwarding companies nowdays. Freight forwarder is an agency or operator that regulates the delivery / receiving activities of goods involving several modes of transportation by using some documents required and the State associated with the activity(Sari, 2015). The growth of freight forwarder companies because the profits quite large(Nurlita et al., 2016). Due to the increasing demand for air freight shipment, the company needs to make sure that all the shipments are being handled well,and also the main responsibility of the forwarder is to protect the interests of its customers or shippers(ICAO \& WCO, 2013). Competition between freight forwarder companies is not just about the number of shipment that being obtained by the company. It is also 
about the quality and the punctuality of the service that been provide(Setiawan, 2015).

Cargo refers to goods carried by a large vehicle, like a plane, ship, train,or truck. There are many types of goods that will be delivered and each type of it sometimes needs a different kind of handling (Zamora, 1975) .

Cargo handling service is an important part in delivering cargo from origin to destination. Cargo handling means the whole process starting from the company receiving the cargo until it is moved into vehicle and transport it to the destination, unload the cargo at the destination and cargo finally is received by the consignee.

In cargo handling services not only forwarders are involved in delivering cargo from origin to destination but many participating parties are involved such as shippers, customs brokers, cargo terminals, ground handling services and airlines(Chao \& Li, 2017) .

In handling the cargo, freight forwarder companies certainly have many problems encountered(Whardana, n.d.). The condition of the goods when received becomes one of the determinants of the successful delivery (Edi, n.d.).The most frequent problems in logistics service is cargo damage.

Cargo damage is cargo that in the process of receiving or shipping is not in accordance with applicable standard operation procedure. The cargo is found damaged either packing, content or quality of the cargo itself such as broken, hole in, tape torn, seams open, tape loose, dented, torn, crushed, wet, deteriorated, and mortality.

There are several people in the business of trading, who do not know or understand the types of damage to cargo, how it can happen, why it happens, how it can be prevented and what needs to be done when faced with a cargo damage claim.

For the example here are the data from a freight forwarder company Yusen Logistics Indonesia. Yusen Logistics Indonesia offers global logistics services to meet customer need and customizes solutions to handle cargo in a timely and cost efficient way. 
Table 1. Shipment October PT Yusen Logistics Indonesia

\begin{tabular}{|c|c|c|c|c|}
\hline Airline Code & $\begin{array}{l}\text { No Of } \\
\text { Ship / } \\
\text { Month } \\
\end{array}$ & $\begin{array}{c}\text { Quality } \\
\text { Performance }\end{array}$ & $\begin{array}{l}\text { Damage } \\
\text { at Origin } \\
\text { Terminal }\end{array}$ & $\begin{array}{c}\text { Damage at } \\
\text { Destination } \\
\text { Terminal } \\
\end{array}$ \\
\hline All Nippon Airways & 52 & $100 \%$ & 0 & 0 \\
\hline Cathay Pacific & 161 & $98 \%$ & 0 & 4 \\
\hline Cebu Airlines & 15 & $87 \%$ & 0 & 2 \\
\hline China Airlines & 38 & $100 \%$ & 0 & 0 \\
\hline Emirates & 11 & $82 \%$ & 0 & 1 \\
\hline Etihad & 15 & $100 \%$ & 0 & 0 \\
\hline Garuda Indonesia & 57 & $98 \%$ & 0 & 1 \\
\hline Japan Airlines & 113 & $100 \%$ & 0 & 0 \\
\hline KLM & 25 & $96 \%$ & 0 & 1 \\
\hline Korean Airlines & 17 & $100 \%$ & 0 & 0 \\
\hline Lufthansa Cargo & 6 & $100 \%$ & 0 & 0 \\
\hline Malaysian Airlines & 19 & $95 \%$ & 0 & 0 \\
\hline Nippon Cargo Airline & 2 & $100 \%$ & 0 & 0 \\
\hline Qantas & 10 & $80 \%$ & 0 & 2 \\
\hline Qatar Airlines & 19 & $89 \%$ & 0 & 0 \\
\hline Singapore Airline & 69 & $99 \%$ & 0 & 1 \\
\hline Mihin Lanka & 16 & $100 \%$ & 0 & 0 \\
\hline Thai Cargo & 24 & $100 \%$ & 0 & 0 \\
\hline Asiana & 41 & $100 \%$ & 0 & 0 \\
\hline Oman Air & 1 & $100 \%$ & 0 & 0 \\
\hline Raya Air & 1 & $100 \%$ & 0 & 0 \\
\hline Turkish Air & 9 & $100 \%$ & 0 & 0 \\
\hline
\end{tabular}

From the data above, we can see the delivery of yusen logistics using airlines in October. It can be concluded that the damage to cargo often occurs at the destination terminal and most often occurs in cathay pacific because the shipment runs most on cathay pasific. However, based on the quality performance indicator of airlines that is chosen to have the lowest performance is qantas airways with $80 \%$ rate of 10 deliveries, damage occurs 2 time. Quality performance indicator means 100\% perfect, 99\%$80 \%$ excellent, $79 \%-70 \%$ good and $69 \%-0 \%$ poor. 


\section{Method}

The method used to collect data was using fishbone diagram and interview. Fishbone diagrams was used to obtain the possible causes of cargo damage and the interview was used to know the real situation on the field and also interact directly with the workers there.

Fishbone diagrams also known as cause-and-effect diagrams identifies many possible cause for an effect or problem (Phillips \& Simmonds, 2005).

Fishbone diagrams also known as "Ishikawa Diagrams" because it was created by Mr. Kaoru Ishikawa, it is defined as a fishbone because the diagrams looks like a fish skeleton (Kanti Bose, 2012). This method is suitable to solve damaged cargo problem. As we know, there is a lot of things that cause damaged cargo, but sometimes people don't realize that.

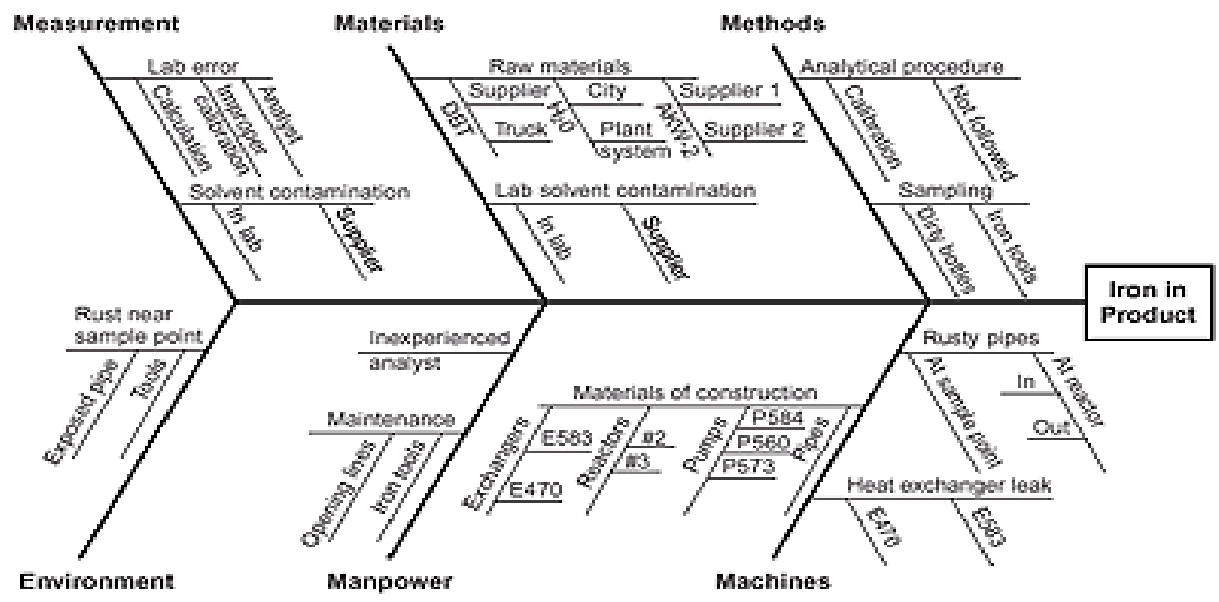

Figure 1. Sources : asq.org

Interview in qualitative research is a conversation where questions are asked to get information.

In-depth interviews can be defined as a qualitative research technique which involves "conducting intensive individual interviews with a small number of respondents to explore their perspectives on a particular idea, program or situation" (Boyce and Neale, 2006, p.3).

A qualitative research interview seeks to cover both a factual. Interviews are useful for getting the stories and opinion behind the staff cargo experiences (Valenzuela \& Shrivastava, 2002). 


\section{Discussion and Result}

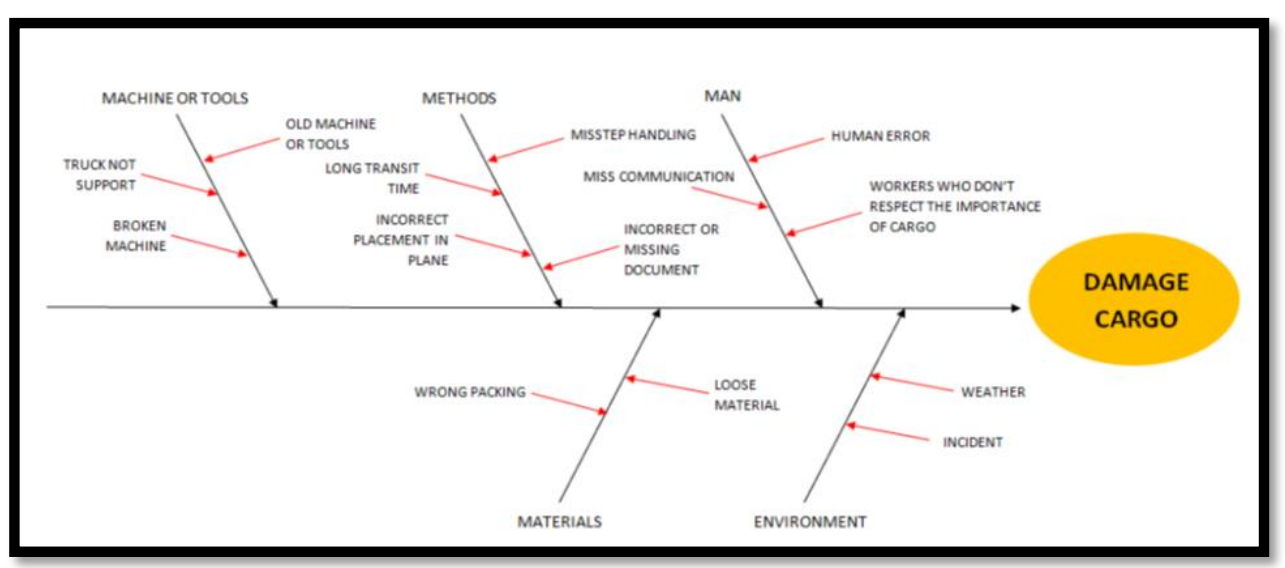

Figure 2. Fishbone diagrams

Here above the fishbone diagram for damaged cargo. As we can see, there are five main causes of damage cargo ( man, methods, machine or tools, environment, materials).

First, man or human are the one that has a big responsibility in delivering cargo because every cargo's movement is done by humans and controlled by humans too. To gain success humans must be directed and motivated well, if it is not, it will be very difficult for the organization to achive the goals (Sturges \& Kilani, 1992). Coordination among all the employees is also needed to be done and it is also required to specify about their individual responsibilities (Kanti Bose, 2012). Even though, there is a lot of problems that can be caused by human :

a. Human error : human error is a mistake made by humans. This mistakes usually occurs because of unconcentrated while working and gets a lot of distraction while working.

b. Workers who don't respect the importance of cargo : this problem happens when workers throw the cargo and treat the cargo badly

c. Miss communication: Communication has a very important role in an organization, group or company. This is also very important among freight forwarder, shipper, airlines, overseas and consignee. It is very important for the freight forwarding company builds a good network 
with the whole concerned parties(Whardana, n.d.). This problem happens because of the bad coordination between the parties.

Second, Method is a procedure, techinique or a way in delivering cargo. How to handle the cargo? If the methods used is correct then the result will be good. Here are the problems that can be caused by method in delivering cargo:

a. Misstep handling : This problems seriously affects the customer's cargo's conditions. All workers must ensure that in carrying out cargo, it must be handled in accordance with standard operating procedures.

b. Incorrect or missing documents : This problem will seriously affect cargo's handling because if the document that has been given is incorrect or wrong then the cargo can't be handled properly. And if there's missing document associated with how the cargo's must be handled then it will affect the cargo's condition too.

c. Long transit time: If the delivery has a long time flight schedule and a lot of transits with long waiting time, it will increase the possibility of cargo damage because it has been through many stops and different paths in handling cargo.

d. Incorrect placement in plane: placement of an item in the aircraft can affect the conditions of the goods. placement must be appropriate based on the type of the goods and it is to reduce the possibility of cargo from damage.

Third, Machine or tool has an important role in handling and delivering cargo.

a. Old machines or tools: the condition of an equipment such as age and quality will affect the occurence of work accidents. The old tools are likely to be damaged. If the tools damage, of course it can lead to an accident.

b. Truck not support : there is many kind of cargo which needs a different kind of truck when it is being loaded, if the parties involved use a truck which doesn't support the cargo's type, it can lead to the cargo being 
damage. So, the parties need to make sure that the truck is suitable for the cargo.

c. Broken machine or tools: if there's something broken on the machine or tools while it is being used to handle the cargo, it can be the initial source of damaged cargo.

Fourth, Environment means the condition in origin until destination from shipper until consignee such as factory - airline warehouse - airline airline warehouse destination - consignee. Many possibilities can happen because of this environment. Cargo going through many circumstances or situation which is different from its delivery such as:

a. Weather : the weather is often used as an excuse when the delivery of cargo is damaged because the weather is part of nature that can't be prevented and difficult to predict. Weather such as rainy or snowy.

b. Incident: any deliveries can potentially occur unexpected and undesirable incidents such as traffic accident or wildfire.

Fifth, Material means the things that are used as materials packing and also as a complement in delivery goods which may cause the cargo load to be damaged. Material management is key to ensuring the successful of supply chain management in delivering cargo (Kanti Bose, 2012).

a. Wrong packing : wrong packing happens when the materials which is used is not appropriate with the goods inside. All parties must be aware of applicable standards.

b. Loose material : the materials which is used to pack the goods is not in a tight and correct condition.

For the interview result, we give the statement to approximately 20 staff cargo about causes why cargo being damage and received the answer below: 
Table 2. staff assessment

\begin{tabular}{|c|l|c|}
\hline No & \multicolumn{1}{|c|}{ Statement } & $\begin{array}{c}\text { Staff agree about the } \\
\text { statement }\end{array}$ \\
\hline 1 & $\begin{array}{l}\text { The cargo staff must have a basic knowledge of } \\
\text { cargo and have a basic cargo certificate }\end{array}$ & $92.3 \%$ \\
\hline 2 & $\begin{array}{l}\text { The forwarder informs to the shipper that every } \\
\text { cargo sent must use the appropriate packing rules }\end{array}$ & $92.3 \%$ \\
\hline 3 & $\begin{array}{l}\text { The forwarder shall notify the shipper in case of } \\
\text { incompatibility with the cargo to be shipped }\end{array}$ & $100 \%$ \\
\hline 4 & $\begin{array}{l}\text { Implementation of cargo handling in accordance } \\
\text { with applicable SOP (standard operating procedure) }\end{array}$ & $92,3 \%$ \\
\hline 5 & $\begin{array}{l}\text { The cargo material used is not in accordance with } \\
\text { the provisions of IATA }\end{array}$ & $53,8 \%$ \\
\hline 6 & $\begin{array}{l}\text { The quality of cargo material used is poor } \\
\text { The condition of packing cargo is not in proper } \\
\text { condition }\end{array}$ & $30,8 \%$ \\
\hline 8 & \begin{tabular}{l} 
Unpredictable weather \\
\hline 9
\end{tabular} & $\begin{array}{l}\text { Unexpected events such as accidents or fires } \\
\text { The airlines warehouse staff must have basic cargo } \\
\text { knowledge }\end{array}$ \\
\hline 10 & $\begin{array}{l}\text { The airlines warehouse staff must handle the cargo } \\
\text { in accordance with the applicable SOP (standard } \\
\text { operating procedure) }\end{array}$ & $92,3 \%$ \\
\hline 12 & $\begin{array}{l}\text { The cargo store must have complete facilities and } \\
\text { supporting equipment to support the cargo handling } \\
\text { process }\end{array}$ & $100 \%$ \\
\hline 13 & The airlines provide long transit time & $100 \%$ \\
\hline 14 & The airlines provide many transit locations & $46,2 \%$ \\
\hline & \multicolumn{2}{|c|}{\begin{tabular}{l}
$53,8 \%$ \\
\hline
\end{tabular}} \\
\hline
\end{tabular}

From the data above the higher persentage that being received means that it must be improve to reduce the possibility of damage cargo. If we make a correlation between the statement and the fishbone then things that need improvement the most is the ability of man power (humans).

Humans become the main cause of cargo damage because every shipment cargo is done by human and controlled by human so humans have a big responsibility in delivering cargo successfully.

After that from the interview, the frequency of the most damaged cargo is packing torn. Why packing torn? Because mostly from shipment, shipper doesn't over pay attention about the quality of cargo material for packaging. The second frequent of damaged cargo is dent. Dent occurred due to lack of caution of various parties. And for the third frequent of damaged cargo is wet because unpredictable weather and bad packaging. 


\section{Conclusion}

From the discussion above, the paper is to reduce the damaged cargo. The conclusion are the following:

- Type of damage which often occurs are torn, dent and wet

- The skills and ability of the staff are very required

- Palletized shipment requires to ensure the pallet is in appropriate size and strong to keep the load stable during handling \& transportation(Singh, Singh, Antle, Topper, \& Grewal, 2014)

- The best and easiest way to prevent damage is to properly prepare the freight according to the correct standard operation procedure.

- Tricks that can be used to avoid the trucks problems in avoiding damaged cargo:

Cargo with large dimensions and weight should be placed at the bottom of the truck and the truck must also be empty and full and avoid the empty space in the truck. Empty space can fit with additional devices such as wooden beams, airbags and others in loading with safe loading methods (Singh et al., 2014)

- Important for the sender to ensure that a good quality pallet is used. Low-quality wooden or plastic pallets that are not designed to carry loads and facilitate handling big cargo can cause damage of product or potentially broken.

- Double wrapping is also can be one of the solution to make sure the cargo is already well preserved.

- Use the appropriate labels based on the types of goods to make sure the goods is being handled with the right ways.

- Place the goods remarks on the packing to be easily identified.

\section{References}

Azadian, F., Murat, A., \& Chinnam, R. B. (2017). An unpaired pickup and delivery problem with time dependent assignment costs: Application in air cargo transportation. European Journal of Operational Research, 263(1), 188-202. https://doi.org/10.1016/j.ejor.2017.04.033 
Chao, C. C., \& Li, R. G. (2017). Effects of cargo types and load efficiency on airline cargo revenues. Journal of Air Transport Management, 61, 26-33. https://doi.org/10.1016/j.jairtraman.2015.11.006

Edi, D. W. (n.d.). Biaya Logistik Dan Kelancaran Pengiriman Logistic Costs and the Good' S Delivery, 3(2), 227-243.

ICAO, \& WCO. (2013). Moving Air Cargo Globally. Retrieved from http://www.icao.int/Security/aircargo/Documents/ICAO-

WCO_Moving-Air-Cargo_2013.EN.pdf

Kanti Bose, T. (2012). Application of Fishbone Analysis for Evaluating Supply Chain and Business Process- A Case Study on the ST James Hospital. International Journal of Managing Value and Supply Chains, 3(2), 17-24. https://doi.org/10.5121/ijmvsc.2012.3202

Nurlita, L., Sekolah, S., Manajemen, T., Trisakti, T., Made, I., Sekolah, A., ... Trisakti, M. T. (2016). Loyalitas Pelanggan Pada Perusahaan Freight Forwarding Customer Loyalty of Freight Forwarding Company, 3(3), 299-308.

Phillips, J., \& Simmonds, L. (2005). Using fishbone analysis to investigate problems. Nursing Times, 109(15), 18-20. Retrieved from http://www.ncbi.nlm.nih.gov/pubmed/23696993

Sari, L. M. (2015). PENGIRIMAN PRODUK ARNOTTS KE ALFAMART AREA JABODETABEK DAN BANTEN PT INTAN UTAMA LOGISTIK TAHUN 2015, (3), 11-20.

Setiawan, A. (2015). BUSINESS STRATEGY OF PT MONANG SIANIPAR ABADI ( MSA ) CARGO SOEKARNO HATTA CENGKARENG IN 2015, 35-45.

Singh, P., Singh, J., Antle, J., Topper, E., \& Grewal, G. (2014). Load Securement and Packaging Methods to Reduce Risk of Damage and Personal Injury for Cargo Freight in Truck, Container and Intermodal Shipments. Journal of Applied Packaging Research, 6(1), 47-62. https://doi.org/10.14448/japr.01.0005

Sturges, R. H., \& Kilani, M. I. (1992). Towards an integrated design for an assembly evaluation and reasoning system. Computer-Aided Design, 24(2), 67-79. https://doi.org/10.1016/0010-4485(92)90001-Q

Valenzuela, D., \& Shrivastava, P. (2002). Interview as a method for qualitative research. ... . Asu. Edu/ kroel/www500/Interview\% ..., 120. https://doi.org/0018726708094863

Whardana, F. T. (n.d.). G- TRANE INFORMATION SYSTEM AND EMPLOYEES' PERFORMANCE AIR FREIGHT DEPARTMENT OF PT NISSIN TRANSPORT INDONESIA, 59-68.

Zamora, S. (1975). Carrier Liability for Damage or Loss to Cargo in International Transport. American Journal of Comparative Law, 23(3), 391-450. Retrieved from http://www.jstor.org/stable/839373

http://asq.org/learn-about-quality/cause-analysistools/overview/fishbone.html (downloaded on November 10, 2017)

https://research-methodology.net/research-methods/qualitative-research/interviews/ (downloaded on November 10,2017) 